\title{
Presentation: introducing the Dossier
}

Cultural Studies and Postcolonialism share an imbricated history as academic disciplines. The former developed from literary studies in the 1950's, consolidating a different stance towards traditional ways of knowing in the Social Sciences. The latter emerged in the 1980's as a denunciation against the political effects that knowledgeinvested representations exerted on non-Western subjects. Profiting from the tensions between Marxism and poststructuralism, both frameworks of analysis advanced critical perspectives through an innovative engagement with contemporary artifacts of culture. These approaches allowed for the incorporation of new topics in the research agenda of established disciplines, blurring the lines between Philosophy, Sociology, Anthropology, History and the other Social Sciences. In the realm of Political Science and International Relations (IR), the influence of Cultural Studies and Postcolonialism is still a minor one though. Despite the relentless efforts to structure an alternative treatment of politics, the contributions of critical theorists remain marginalized because they do not accord with the disciplinary identity that defines their boundaries.

In this sense, this Dossier presents contributions that challenge Political Science's disciplinary boundaries by opening up space for the reimagination of politics. They incorporate a broader understanding of global politics that accommodates perspectives drawn from Cultural Studies and Postcolonialism. The authors offer aesthetically-oriented reflections on subjects like racism, coloniality, inequality, migration, gender and political violence through the treatment of cultural artifacts like literature, music, film, photography, TV broadcasts and other manifestations.

In the first contribution, Michael J. Shapiro's paper on Michael Haneke's Caché inquires into the way visual arts intervene to disclose and unsettle perspectives on the inequalities within the metropolitan venues in which immigrant populations from former colonies dwell and provide the historical context of the hegemonic structures that such interventions seek to challenge. The inquiry follows a family whose personal memories of a wrong perpetrated on an Algerian foster child is an allegory of France's willful amnesia about the security forces' October 1961 attack on Algerian demonstrators.

Fabiano P. Mielniczuk attempts to pave the theoretical way to substitute the political for politics. After illustrating how mainstream IR theories reify the State as the dominant form of subjectivity, he explores the power ontology shared by the critics of this mode of representation departing from Foucault's analytics of power. By reading Darby's The Fiction of Imperialism and Said's Orientalism through the 
Foucauldian categories of strategy and tactics, he attempts to illustrate how the power-as-productive figuration can be deployed to destabilize the juridico-discursive one as a way of locating where cultural studies and postcolonialism meet global politics.

"Becoming untimely: towards a postcolonial regime of aesthetics", by Rohan Kalyan, discusses on the construction of a postcolonial regime of aesthetics, arguing that works on this genre demonstrate the postcolonial ambivalence as a productive site of cultural mediation, using it to interrogate the invention of national imaginaries that were often a response to the imposition of colonial and imperial violence.

On "The culture of time and the horizons of futurity", Francine Rossone de Paula argues on how the inclusion of cultural difference in global studies either are addressed by the agenda of democratization or treated as a redemptive historicization. In this sense, she explores the mobilization of futurity, through the disruptive capacities manifested on aesthetics of Afrofuturism, Indigenous Futurism and Queer Futurism in inspiring other time-spaced realities, differing from geohistorical reclamations regarding the global south.

In the following paper, "Lens distortion: image capture, racism and subversion from colonial photography to the iborder", by the author Lorenzo Rinelli, explores racism from the increased use of facial recognition technologies on migration management as a link to the early use of camera by Europeans as a tracking tool in colonial times.

Regarding the postcolonial debates on feminism, at "Fatema Mernissi's writings as a gateway to postcolonial islamic feminisms and intersectionality in the Maghreb”, Jessica da Silva Correia de Oliveira addresses the lack of debate between Western and non-Western feminism and gender scholars by examining the work of Moroccan sociologist Fatema Mernissi as an important link to enrich the ties between Western and Islamic feminists.

The last paper of this dossier is named "Meditations on the Sacrificial Egg". Based on Chinua Achebe's short story, Sam Okoth Opondo examines how the author treats questions of conversion, immunity/community, the passage of beliefs, curses, and knowledge from one generation to another (or even to a strangers), reflecting on the politics of knowledge, genre, citation/attribution, and ethics of cohabitation.

Alongside this Dossier, there is also one free themed article included in this issue, written in Spanish by Federico Travesa, named "Los límites de neoinstitucionalismo: las coyunturas críticas y la contingencia como negación del poder". Traversa states that the neo-institutionalism theory was not able to discuss power 
asymmetries in politics properly, and, in this sense, he proposes a new approach to the conception of critical conjecture, developing two other classifications, namely "cambio acotado" and "institucionalización focal".

Fabiano P. Mielniczuk

(Universidade Federal do Rio Grande do Sul/ Brasil)

Michael J. Shapiro

(University of Hawai'i/ United States of America) 